\title{
Pengaruh Pendekatan Saintifik Terhadap Keterampilan Berpikir Kritis Siswa Subtema Keberagaman Makhluk Hidup Di Lingkunganku Kelas IV Sekolah Dasar
}

\section{Nurul Agustin}

Program Studi Pendidikan Guru Sekolah Dasar, STAI Al-Azhar nurulagustin_pgsd07@yahoo.com

\begin{tabular}{|c|c|}
\hline Kata Kunci: & Abstrak \\
\hline $\begin{array}{l}\text { Pendekatan } \\
\text { saintifik, } \\
\text { Kemampuan } \\
\text { berpikir kritis }\end{array}$ & $\begin{array}{l}\text { Penelitian ini bertujuan untuk mengetahui pengaruh pendekatan saintifik terhadap } \\
\text { kemampuan berpikir kritis siswa kelas IV SD. Penelitian ini dilakukan di SDN } \\
\text { Jatikalang II Krian dengan subjek penelitian adalah siswa kelas IV tahun pelajaran } \\
\text { 2018/2019. Penelitian ini merupakan Penelitian Tindakan Kelas (PTK). Penelitian jenis } \\
\text { kualitatif ini dilaksanakan dalam } 2 \text { siklus, peneliti menggunakan teknik observasi, } \\
\text { dokumentasi, dan tes untuk memperoleh data. Teknik analisis data melalui tahap } \\
\text { reduksi data, penyajian data dan penarikan kesimpulan dan verifikasi serta triangulasi } \\
\text { data. Objek penelitian yaitu meningkatkan kemampuan berpikir kritis siswa yang } \\
\text { dilihat melalui hasil tes setiap akhir siklus I dan II serta hasil observasi, dokumentasi } \\
\text { dan wawancara. Hasil penelitian menunjukkan bahwa kemampuan berpikir kritis siswa } \\
\text { dapat ditingkatkan melalui pendekatan saintifik pada subtema keberagaman makhluk } \\
\text { hidup di lingkunganku. Hasil pertama menunjukkan bahwa kemampuan berpikir kritis } \\
\text { siswa pada kelas IV. Hal ini ditunjukkan dengan hasil tes kemampuan berpikir kritis, } \\
\text { persentase untuk kemampuan berpikir kritis siswa mengalami peningkatan dari rata- } \\
\text { rata 71, 77\% atau dalam kategori tinggi menjadi 87, 71\%. Dengan demikian, } \\
\text { kemampuan berpikir kritis siswa termasuk dalam kriteria sangat tinggi. Berarti ada } \\
\text { pengaruh pendekatan saintifik terhadap kemampuan berpikir kritis. Dengan demikian } \\
\text { dapat disimpulkan bahwa pendekatan saintifik berpengaruh terhadap kemampuan } \\
\text { berpikir kritis. }\end{array}$ \\
\hline Keywords: & Abstract \\
\hline $\begin{array}{l}\text { Scientific } \\
\text { approach, } \\
\text { Critical } \\
\text { thinking skills }\end{array}$ & $\begin{array}{l}\text { This study aim was to describe the effect of the scientific approach to critical thinking } \\
\text { skills of fourth grade students. This research was conducted at Jatikalang II Krian } \\
\text { Elementary School with the research subject being fourth grade students in the } \\
2018 / 2019 \text { academic year. This study is a Classroom Action Research (CAR). This } \\
\text { type of qualitative research was carried out in } 2 \text { cycles, researchers used observation, } \\
\text { documentation, and test techniques to obtain data. The technique of analyzing data is } \\
\text { through the stages of data reduction, data presentation and conclusion drawing and } \\
\text { verification and data triangulation. The object of research is to improve students' } \\
\text { critical thinking skills which are seen through the test results at the end of the first and } \\
\text { second cycles and the results of observations, documentation and interviews. The } \\
\text { results showed that students' critical thinking skills could be improved through a } \\
\text { scientific approach to the sub-themes of diversity of living things in my environment. } \\
\text { The first results show that students' critical thinking skills in class IV. This is indicated } \\
\text { by the results of the critical thinking ability test, the percentage for students' critical } \\
\text { thinking skills has increased from an average of } 71,77 \% \text { or in the high category to } 87 \text {, } \\
71 \% \text {. Thus, students' critical thinking skills are included in the criteria of very high. } \\
\text { Means there is an influence of the scientific approach to critical thinking skills. Thrus it } \\
\text { can be concluded that the scientific approach affects the ability to think critically }\end{array}$ \\
\hline
\end{tabular}




\section{A. Pendahuluan}

Kurikulum 2013 menekankan pada dimensi pedagogik modern dalam pembelajaran, yaitu menggunakan pendekatan saintifik. Pendekatan saintifik adalah suatu pendekatan dalam Kurikulum 2013 yang digunakan dalam proses pembelajaran yang meliputi dimensi pengamatan, penalaran, penemuan, pengabsahan, dan penjelasan tentang suatu kebenaran. Pendekatan saintifik yang dimaksudkan dalam penelitian ini adalah suatu pendekatan atau salah satu metode pembelajaran yang digunakan oleh guru dan siswa kelas IV SD dalam pembelajaran berupa mengamati, menanya, menalar, mencoba, dan menciptakan.

Pendidikan di Sekolah Dasar (SD) sebagai sebuah tahap awal untuk melanjutkan belajar ke jenjang yang lebih tinggi, merupakan bekal hidup ketika bergaul di masyarakat. Oleh karena itu, pendidikan di SD saat ini disinyalir belum menunjukkan indikasi ke arah pembelajaran mandiri yang mampu menyadarkan peserta didik bahwa hakikat dia belajar di sekolah adalah sebagai modal awal dalam pergaulan di masyarakat. Akan tetapi, yang terjadi di lapangan kaitannya dengan pendidikan di SD tidak lebih hanya mempersiapkan mental siswa untuk menghadapi ujian semester, sedangkan penanaman kesadaran manfaat ilmu bagi peserta didik sering kali terabaikan.

Kurikulum 2013 adalah kurikulum yang berbasis kompetensi yang dirancang untuk mengantisipasi kebutuhan kompetensi abad 21 (Nuh, 2014). Pada abad ini, kemampuan kreativitas dan komunikasi akan menjadi sangat penting. Sejalan dengan itu, rumusan kompetensi sikap, pengetahuan, dan keterampilan yang ada dalam Kurikulum 2013 ditujukan untuk menciptakan kreativitas dan komunikasi.

Menurut Dyers, 2/3 dari kemampuan kreativitas seseorang diperoleh melalui pendidikan, $1 / 3$ sisanya berasal dari genetik. Pendidikan dijadikan salah satu upaya untuk mengembangkan kreativitas melalui penularan-penularan yakni menularkan kreativitas individu ke individu lain. Stimulus tersebut digunakan untuk membuat imajinasi baru pada individu. Hal tersebut menjelaskan bahwa kreativitas merupakan aktivitas yang dapat dipelajari bersama.

Kompetensi yang diharapkan dari seorang lulusan SD/MI harus memiliki kemampuan pikir dan tindak yang produktif dan kreatif dalam ranah abstrak dan konkrit. Kemampuan tersebut diperjelas dalam kompetensi inti yang salah satunya adalah menyajikan pengetahuan dalam bahasa yang jelas, logis dan sistematis dalam karya yang estetis atau dalam tindakan yang mencerminkan perilaku anak sehat, beriman, dan berakhlak mulia. Kompetensi tersebut dirancang untuk dicapai melalui proses pembelajaran berbasis penemuan (discovery learning) melalui kegiatan-kegiatan berbentuk tugas (projectbased learning) yang mencakup prosesproses yaitu mengamati, menanya, mencoba, menalar, dan mengkomunikasikan.

Pencapaian kompetensi terpadu seperti rumusan di atas, menuntut pendekatan pembelajaran tematik terpadu, yaitu mempelajari semua muatan pelajaran secara terpadu melalui tema-tema kehidupan yang dijumpai peserta didik sehari-hari. Peserta didik diajak mengikuti proses pembelajaran transdisipliner dimana kompetensi yang diajarkan dikaitkan dengan konteks peserta didik dan lingkungannya. Materi-materi muatan pelajaran dikaitkan satu sama lain sebagai satu kesatuan membentuk pembelajaran multidisipliner dan inter-disipliner untuk menghindari tumpang tindih dan ketidakselarasan antar materi mata pelajaran. Tujuannya adalah tercapainya efisiensi materi yang harus dipelajari dan efektivitas penyerapannya oleh peserta didik. Pengalaman belajar dalam Kurikulum 2013 mengarah pada pengalaman belajar yang bermakna untuk membangun sikap dan perilaku positif, penguasaan konsep, keterampilan berpikir saintifik, berpikir tingkat tinggi, kemampuan menyelesaikan masalah, inkuiri, kreativitas, dan pribadi reflektif (Permendikbud No. 65). 
Proses pembelajaran sebagian besar masih menjadikan anak tidak bisa, menjadi bisa. Kegiatan belajar berupa kegiatan menambah pengetahuan, kegiatan menghadiri, mendengar, dan mencatat penjelasan guru, serta menjawab secara tertulis soal-soal yang diberikan saat berlangsungnya ujian. Pembelajaran baru diimplementasikan pada tataran proses menyampaikan, memberikan, mentransfer ilmu pengetahuan dari guru kepada siswa.

Proses pembelajaran pada kurikulum 2013 dikembangkan atas prinsip pembelajaran siswa aktif melalui kegiatan mengamati (melihat, membaca, mendengar, menyimak), menanya (lisan, tulis), menganalisis (menghubungkan, menentukan keterkaitan, membangun cerita/konsep), mengkomunikasikan (lisan, tulis, gambar, grafik, chart, dan lain-lain). Selain itu, proses pembelajaran dilaksanakan secara berkesinambungan antara satu pertemuan ke pertemuan lainnya dan saling memperkuat antara satu mata pelajaran dengan mata pelajaran yang lain. Proses pembelajaran pada kurikulum 2013 mencirikan bahwa proses pembelajaran hendaknya terintegrasi, relevan dan bekesinambungan.

Relevansi materi pada proses pembelajaran perlu diperhatikan. Untuk mengetahui relevansi materi perlu adanya analisis-analisis mengenai kebutuhan yang ada dalam diri siswa. Tanpa adanya relevansi dan integrasi pada suatu materi, siswa akan sering lupa mengenai mata pelajaran yang telah diterima pada minggu kemarin bahkan tahun lalu. Hal ini menjelaskan bahwa materi yang tidak terhubung dan tidak sesuai dengan kebutuhan siswa menjadikan siswa tidak aktif dan mudah melupakan.

Dalam tataran ini siswa yang sedang belajar bersifat pasif, menerima apa saja yang diberikan guru, tanpa diberikan kesempatan untuk membangun sendiri pengetahuan yang dibutuhkan dan diminatinya. Siswa sebagai manusia ciptaan Tuhan yang paling sempurna di dunia karena diberi otak, dibelenggu oleh guru. Sudah seharusnya siswa diberdayagunakan, difasilitisi, dimotivasi, dan diberi kesempatan untuk berpikir, bernalar, berkolaborasi untuk mengkonstruksi pengetahuan sesuai dengan minat dan kebutuhannya serta diberi kebebasan untuk belajar. Pemahaman yang keliru bahkan telah menjadi "mitos" bahwa belajar adalah proses menerima, mengingat, mereproduksi kembali pengetahuan yang selama ini diyakini.

Menurut Smith dalam Johnson S (1977), keterampilan berpikir adalah mencoba untuk mengembangkan kemampuannya berpikirnya. Kemampuan yang dapat membantu siswa mencapai tingkat pemahaman sendiri. Pemikiran kritis dan analitis ada secara alami pada beberapa murid, tetapi bagi sebagian murid lainnya hal ini adalah perkenalan yang baru dan menarik pada kekuatan otak mereka (Johnson, 2009).

Mencoba merupakan keterampilan berfikir yang cenderung mencari tahu dibandingkan diberi tahu sesuatu hal. Proses berfikir mencoba menggambarkan bahwa setiap individu memiliki imajinasi dan keinginan yang tinggi untuk mengimplementasikan apa yang telah dipahami. Setiap individu ingin secara bebas mengeksplorasi ide-ide yang ada pada dirinya. Kebebasan dalam mengeksplorasi ide-ide digunakan untuk melihat potensi dan kreativitanya dalam suatu hal.

Karakteristik siswa SD pada masa kelas tinggi (kelas 4,5, dan 6) meliputi: (1) perhatiannya tertuju pada kehidupan praktis sehari-hari; (2) ingin tahu, ingin belajar, dan realistis; (3) timbul minat pada pelajaran-pelajaran khusus; dan (4) anak memandang nilai sebagai aturan yang tepat mengenai prestasi belajarnya di sekolah (Ahmadi dan Prasetya, 2005). Dari karakteristik siswa SD kelas tinggi ini terlihat bahwa, diperlukan suatu kegiatan belajar (aktivitas belajar) yang dapat mendukung siswa mendapatkan hal tersebut. Menurut Hamalik (2009:171) "dalam pengajaran modern lebih menitikberatkan pada aktivitas sejati, yaitu siswa belajar dengan bekerja untuk memperoleh pengetahuan, pemahaman, dan aspek-aspek tingkah laku lain, serta 
dapat mengembangkan keterampilan yang bermakna untuk hidup di masyarakat”.

Berdasarkan karakteristik ini, salah satu pendekatan pembelajaran yang dapat digunakan adalah pendekatan saintifik. Pendekatan saintifik merupakan pendekatan yang dipakai dalam pembelajaran dengan meliputi mengamati, menanya, mencoba, mengolah, menyajikan, menyimpulkan, dan mencipta untuk semua mata pelajaran. Proses pembelajaran harus menerapkan nilai-nilai atau sifat-sifat ilmiah dan menghindari nilai-nilai atau sifat-sifat non ilmiah.

Pendekatan yang dipilih dan digunakan guru dalam mengoptimalkan proses berfikir siswa, hendaknya tidak membatasi pengetahuannya. Proses pendekatan menawarkan pengetahuan faktual dan pertukaran pengetahuan. Pengetahuan faktual akan terbentuk apabila subjek mengamati langsung objek, sedangkan pertukaran pengetahuan akan terjadi apabila subjek pernah mengamati objek yang sama, namun berbeda dalam konteks permasalahan.

Pendekatan saintifik merupakan pendekatan yang dapat menghubungkan 3 domain yaitu domain sikap, pengetahuan, keterampilan. Ketiga domain tersebut dapat dibentuk melalui satu aktivitas yakni mengamati, menanya, mencoba, menalar dan mengkomunikasikan. Melalui pendekatan saintifik setiap domain dapat dikontrol dan dikembangkan. Pada pendekatan lainnya, beberapa domain seperti sikap dan keterampilan tidak dapat dikontrol dan dinilai secara objektif.

Sikap dan keterampilan perlu ditumbuh kembangkan dalam diri siswa pada setiap tema dalam pembelajaran Kurikulum 2013. Sikap-sikap ini tersurat dan tersirat dalam Rencana Pelaksanaan Pembelajaran (RPP). Sikap dan keterampilan itu antara lain disiplin, tanggung jawab, kepedulian, perilaku patuh, tertib, mengikuti prosedur, toleran, kerjasama, santun, dan memiliki rasa ingin tahu dalam berinteraksi secara efektif dalam lingkungan sosial, alam belajar, serta dunia dan peradabannya.

Bertolak dari hal di atas, hal yang dirasa harus segera mendapat perhatian yaitu tentang pembelajaran saintifik yang mengarahkan keterampilan berpikir kritis siswa dan mendekatkan siswa dengan dunia nyata. Pembelajaran saintifik merupakan pembelajaran yang mengadopsi langkah-langkah saintis dalam membangun pengetahuan melalui metode ilmiah. Model pembelajaran yang diperlukan adalah yang memungkinkan terbudayakan kecakapan berpikir sains, terkembangkannya "sense of inquiry" dan kemampuan berpikir kreatif siswa. Model pembelajaran yang dibutuhkan adalah yang mampu menghasilkan kemampuan untuk belajar, bukan saja diperolehnya sejumlah pengetahuan, keterampilan, dan sikap, tetapi yang lebih penting adalah bagaimana pengetahuan, keterampilan, dan sikap itu diperoleh peserta didik (Permendikbud No. 65 Thn 2013).

Pembelajaran saintifik tidak hanya memandang hasil belajar sebagai muara akhir, namun proses pembelajaran dipandang sangat penting. Oleh karena itu pembelajaran saintifik menekankan pada keterampilan proses. Model ini menekankan pada proses pencarian pengetahuan dari pada transfer pengetahuan, peserta didik dipandang sebagai subjek belajar yang perlu dilibatkan secara aktif dalam proses pembelajaran, guru hanyalah fasilitator yang membimbing dan mengkoordinasikan kegiatan belajar.

Pembelajaran saintifik lebih menekankan pada penalaran induktif (inductive reasoning) dibandingkan dengan penalaran deduktif (deductive reasoning). Penalaran induktif menempatkan bukti-bukti spesifik ke dalam relasi ide yang lebih luas. Pendekatan saintifik merujuk pada teknik-teknik investigasi, memperoleh pengetahuan baru, atau mengoreksi dan memadukan pengetahuan sebelumnya.

Fokus proses pembelajaran diarahkan pada pengembangan keterampilan siswa dalam 
memproseskan pengetahuan, menemukan dan mengembangkan fakta, konsep, dan nilai-nilai yang diperlukan. Model ini juga tercakup penemuan makna, organisasi, dan struktur ide atau gagasan, sehingga secara bertahap siswa belajar bagaimana mengorganisasikan dan melakukan penelitian. Menurut Houston (1998) dalam Putra, pembelajaran berbasis keterampilan proses sains menekankan pada kemampuan peserta didik dalam menemukan sendiri pengetahuan yang didasarkan atas pengalaman belajar, hukum-hukum, prinsip-prinsip dan generalisasi, sehingga lebih memberikan kesempatan bagi berkembangnya keterampilan tingkat tinggi.

Dengan demikian peserta didik lebih diberdayakan sebagai subjek belajar yang harus berperan aktif dalam memahami pernyataan dan menganalisis sehingga guru lebih berperan sebagai organisator dan fasilitator pembelajaran. Kegiatan pembelajaran yang dilakukan melalui proses mengamati, menanya, mencoba/mengumpulkan data, mengasosiasi/menalar, dan mengkomunikasikan. Siswa diharapkan mampu memberikan ide-ide tindakan yang dapat dilakukan manusia yang berhubungan dengan daur hidup hewan dan tumbuhan.

Berdasarkan latar belakang tersebut dan untuk memperoleh gambaran yang lebih objektif kemampuan berpikir kritis, maka peneliti perlu melakukan penelitian dengan judul "Pengaruh Pendekatan Saintifik terhadap Kemampuan Berpikir Kritis Siswa Subtema Keberagaman Makhluk Hidup Di Lingkunganku Kelas IV Sekolah Dasar".

\section{B. Metodologi}

Metode yang digunakan dalam penelitian ini yaitu Penelitian Tindakan Kelas (PTK). Model penelitian tindakan ialah model spiral yang dikembangkan oleh Kemmis dan Mc Taggart. Penelitian dilaksanakan dalam 2 siklus. Setiap siklus meliputi tahap perencanaan, pelaksanaan/tindakan, observasi dan refleksi. Penelitian dilaksanakan dengan tujuan mendeskripsikan peningkatkan kemampuan berpikir kritis siswa melalui pendekatan saintifik kelas IV sekolah dasar. Kemampuan berpikir kritis siswa dikatakan mengalami peningkatan apabila persentase rata-rata pada indikator tes berpikir kritis mendapat skor $81 \%<\overline{x \leq 100 \%}$ dengan kriteria sangat tinggi.

Teknik pengumpulan data dalam penelitian ini antara lain observasi, tes, dokumentasi dan catatan lapangan. Observasi dilakukan untuk melihat keterlaksanaan pembelajaran menggunakan pendekatan saintifik. Observasi dilakukan oleh peneliti dan guru sebagai observer 2. Selain itu, catatan lapangan dan dokumentasi digunakan untuk melihat kegiatan yang terjadi selama pembelajaran dan memperkuat data. Tes diberikan untuk mengetahui dan mengukur peningkatan kemampuan berpikir kritis siswa setelah pembelajaran menggunakan pendekatan saintifik. Tes berupa soal uraian yang disusun berdasarkan indikator kemampuan berpikir kritis yang akan diteliti. Setelah diperoleh hasil tes dengan beberapa indikator dalam kemampuan berpikir kritis dan ditentukan skor rata-ratanya, kemudian skor rata-rata tersebut dianalisis dan dikualifikasi berdasarkan kriteria penskoran kemampuan berpikir kritis siswa yaitu sebagai berikut.

Tabel 1. Kualifikasi Hasil Persentase Skor Tes Kemampuan Berpikir Kritis Siswa

\begin{tabular}{|l|l|}
\hline Skor & Kriteria \\
\hline $81 \%<\overline{x \leq 100 \%}$ & Sangat Tinggi \\
\hline $61 \%<\overline{x \leq 80 \%}$ & Tinggi \\
\hline $41 \%<\overline{x \leq} 60 \%$ & Sedang \\
\hline $21 \%<\overline{x \leq 40 \%}$ & Rendah \\
\hline $0 \%<\bar{x} \leq 20 \%$ & Sangat Rendah \\
\hline
\end{tabular}

(Sumber: Arikunto dan Abdul (2014: 35) 
Keterangan: $\bar{x}=$ rata-rata nilai tes kemampuan berpikir kritis siswa (dalam\%). Kemudian, Data hasil observasi dan dokumentasi dianalisis dengan mereduksi data, menyajikan data dan membuat kesimpulan. Selanjutnya, untuk mengetahui data yang telah diperoleh dari observasi dan dokumentasi apakah menghasilkan data yang sama dilakukan triangulasi data.

\section{Hasil Dan Pembahasan}

Penelitian dilaksanakan mulai tanggal 22 April 2019 sampai 25 April 2019 tahun ajaran 2018/2019 di kelas IV SDN Jatikalang II Krian-Sidoarjo. Penelitian dilaksanakan dalam 2 siklus. Setiap siklus diadakan dua kali pertemuan dengan materi ajar yang sama. Setelah dilaksanakan pembelajaran, diadakan tes untuk setiap siklus. Selanjutnya, hasil tes untuk masing-masing indikator kemampuan berpikir kritis disajikan pada tabel berikut ini:

Tabel 2. Hasil Tes Kemampuan Berpikir Kritis Siklus I dan II

\begin{tabular}{|c|c|c|}
\hline Indikator & $\begin{array}{l}\text { Persentase } \\
\text { Siklus I }\end{array}$ & $\begin{array}{l}\text { Persentase } \\
\text { Siklus I }\end{array}$ \\
\hline Kemampuan menganalisis masalah & $68,85 \%$ & $86,71 \%$ \\
\hline Kemampuan berpikir terbuka/mencari alternatif pemecahan masalah & $72,42 \%$ & $87,71 \%$ \\
\hline Kemampuan membuat kesimpulan & $73,42 \%$ & $87,71 \%$ \\
\hline Mengajukan pertanyaan & 72,42 & 88,71 \\
\hline Rata - rata & $71,77 \%$ & $87,71 \%$ \\
\hline
\end{tabular}

Pada siklus I, siswa pada indikator kemampuan menganalisis masalah memperoleh persentase sebesar 68,85. Berdasarkan hasil tes siswa kurang mampu menganalisis masalah pada soal dan pada siklus ke II mendapatkan persentase sebesar 86,71. Berdasarkan hasil tes siswa mampu menganalisis masalah pada soal. Pada siklus I, siswa pada indikator kemampuan berpikir terbuka/mencari alternatif pemecahan masalah memperoleh persentase sebesar 72,42. Berdasarkan hasil tes siswa kurang mampu berpikir terbuka/ mencari alternatif pemecahan masalah dan pada siklus ke II mendapat persentase sebesar 87,71. Berdasarkan hasil tes siswa mampu berpikir terbuka/mencari alternatif pemecahan masalah.

Pada siklus ke I, siswa pada indikator kemampuan membuat kesimpulan memperoleh persentase sebesar 73,42 berdasarkan hasil tes siswa kurang mampu membuat kesimpulan dan pada siklus ke II memperoleh persentase sebesar 87,71. Berdasarkan hasil tes siswa mampu membuat kesimpulan.

Pada siklus ke I, siswa pada indikator mengajukan pertanyaan memperoleh persentase sebesar 72,42 berdasarkan hasil tes siswa kurang mampu membuat kesimpulan dan pada siklus ke II memperoleh persentase sebesar 88,71. Berdasarkan hasil tes siswa mampu membuat kesimpulan.

Rata-rata hasil tes kemampuan berpikir kritis pada siklus I, memperoleh persentase sebesar 71,77 dan pada siklus ke II memperoleh persentase sebesar 87,71. Dari hasil tes berpikir kritis rata-rata pada siklus ke II menunjukkan siswa mampu berpikir kritis dengan kriteria sangat tinggi.

\section{Kesimpulan}

Berdasarkan pembahasan hasil penelitian dapat ditarik kesimpulan bahwa pembelajaran saintifik mempunyai pengaruh terhadap kemampuan berpikir kritis. Hal ini dapat dilihat dari hasil analisis yang telah dilakukan. Siswa mampu mengidentifikasi setiap informasi yang diterimanya lalu mengevaluasi dan kemudian menyimpulkannya secara sistematis. Siswa juga mampu mengemukakan pendapat dengan cara yang terorganisasi jika dibandingkan dengan 
pembelajaran langsung.

Persentase untuk kemampuan berpikir kritis siswa mengalami peningkatan dari rata-rata 71, 77\% atau dalam kategori tinggi menjadi 87, 71\%. Dengan demikian, kemampuan berpikir kritis siswa termasuk dalam kriteria sangat tinggi. Pada pembelajaran saintifik siswa mempunyai keinginan untuk mencari tahu lebih besar. Hal ini terlihat bahwa, pendekatan menggunakan saintifik mampu membuat siswa aktif mengajukan pertanyaan. Sementara untuk pembelajaran langsung, siswa lebih banyak mendengarkan penjelasan guru kemudian mengerjakan tugas yang diberikan guru.

Dari hasil analisis dapat disimpulkan bahwa pembelajaran saintifik lebih mempunyai pengaruh yang besar dibanding dengan pembelajaran langsung. Pendekatan saintifik dapat meningkatkan kemampuan berpikir kritis.

\section{Daftar Pustaka}

Arikunto, S. (2013). Dasar-dasar Evaluasi Pendidikan. Jakarta: Bumi Aksara

Arikunto, S, dkk. (2015). Penelitian Tindakan Kelas. Jakarta: Bumi Aksara.

Arikunto, S dan Jabar, A. Safruddin. (2014). Evaluasi Program Pendidikan. Jakarta: Bumi Aksara.

Akhmad, Sudrajat. (2013). Pendekatan Saintifik Ilmiah dalam Pembelajaran.

Brookhant, S. (1978). How to Assess Higher Order Thinking Skills in Your Classroom. California: Sage Publication.

Clelan. Tanpa Tahun. "Critical Thinking in Elementary Physical Education". ProQuest. Diunduh tanggal 30 September 2014.

Departemen Pendidikan Nasional. (2007). Panduan KTSP. Jakarta: Depdiknas.

Depdiknas. (2006). Model Pembelajaran Tematik Kelas Awal sekolah Dasar. Jakarta. Pusat Kurikulum, Badan Penelitian dan pengembangan.

Desi. (2012). Pengaruh Pemanfaatan Lingkungan sebagai Sumber Belajar melalui Pendekatan Saintifik terhadap Keaktifan dan Hasil Belajar Siswa Kelas IV Sekolah Dasar (Tesis magister pendidikan tidak dipublikasikan). Universitas Negeri Surabaya.

Ennis, R.H. (1996). Critical Thinking. University of Illionis.

Furchan, Arief. (1982). Pengantar penelitian Dalam Pendidikan. Surabaya: Usaha Nasional

Hadi, S. (2001). Statistik: Jilid 2. Yogyakarta: Andi

Hamalik, Oemar, (1983). Metode dan Kesulitan-Kesulitan Belajar. Bandung. Tarsito

Hamalik, Oemar. (2009). Kurikulum dan Pembelajaran. Jakarta: Bumi Aksara.

Hulfian, Lulu. (2010). Teori-Teori Pembelajaran (Tugas mata kuliah tidak dipublikasikan). Universitas Negeri Surabaya.

Johnson, LouAnne. (2009). Teaching Outside the Box. Newyork: A Harvest Book.

Johnson, S. and Siegel, H. (1977). Teaching Thinking Skills. Cambridge: Porpoise Books.

Kartono,Kartini. (1990). Pengantar Metodologi Riset Sosial. Bandung: Mandar Maju

Kementerian Pendidikan dan Kebudayaan. (2014). Tematik Terpadu Kurikulum 2013. Jakarta: Kemdikbud.

Kementerian Pendidikan dan Kebudayaan. (2014). Tema 3 Keanekaragaman makhluk hidup di lingkung 
Pengaruh Pendekatan Saintifik Terhadap Keterampilan Berpikir Kritis Siswa Subtema Keberagaman

Makhluk Hidup Di Lingkunganku Kelas IV Sekolah Dasar

anku. Jakarta: Kemdikbud.

Kementerian Pendidikan dan Kebudayaan. (2013). Permendikbud Nomor 65: Standar Proses. Jakarta: Kemdikbud

M. Hosnan. (2014). Pendekatan Saintifik dan Kontekstual dalam Pembelajaran Abad 21, Bogor: Ghalia Indonesia

Maksum, A. (2012). Metodologi Penelitian. Surabaya: Unesa University Press.

Mustaji. (2014). "Application of Problem Based Learning in Higher Education". Dalam The Journal of Social Studies

Moleong, Lexy. (2002). Metodologi Penelitian Kualitatif, Bandung: Remaja 